\title{
Reparative processes in jaw bones under using of different plastic materials
}

\author{
Kh. R. Pohranychna \\ Danylo Halytsky Lviv National Medical University; e-mail: pohranychna@ukr.net
}

\begin{abstract}
The comparative experimental study of osseous tissue regeneration in the created foraminous mandibular defects being implanted with bioceramics Kergap T-300 and osteoplastic material Osteopor, as well as justifying the possibility of using the developed reparative material in the maxillofacial surgery clinics based on the analysis of histomorphological research results for are the paper objectives. 78 nonlinear white male rats weighing 240-300 $\mathrm{g}$ with foraminous mandibular defects were used as models for studying impact on the reparative osteogenesis processes made by the bonegraft material. Reparative changes in the implantation sites were studied in real time with the help of histological drugs under the optical microscopy. The graft components were the morphometry object calculated at the percentage ratio per the graft space unit in three cuts from each section. In $27.7 \%$ cases the rats' mandibular defects repair under the natural environment conditions of osseous tissue regeneration achieved with a blood clot was complicated by purulence, the surgical wound dehiscence with pyorrhea or perimandibular abscess. In other cases regeneration caused the development of heterogeneous graft made of chondroid-fibroblastic and osteoid tissues of different organization levels. The comparative experimental morphological and histomorphometric studies of the bone regeneration involving the replacement of created jaw defects with osteoplastic material Kergap-T alone and in the combination with the lyophilized biological placenta implant Osteopor proved that the latter speeded up the beginning of active regenerative processes promoting the early defect filling with the neogenic organotypic osseous tissue comprising 52(43-63)[46-58]\% and 74(57-85)[64-79]\% of the bone graft in 60 and 90 days after the surgical intervention correspondingly (being equal to 24(13-29) [20-28]\% $i$ 32(27-38) [30-34]\% correspondingly in cases when Kergap-T was applied. According to the morphometric research findings, in cases of Osteopor and Kergap-T application the tabular bone element of the graft was equal to 53 (43-60) [46-56]\% and 15(13-18) [14-16]\% correspondingly.
\end{abstract}

Key words: reparative osteogenesis; placenta tissue; bone grafting materials.

\section{INTRODUCTION}

The difficulties of osseous regeneration or replacement after surgical interventions resulted from tumours, gun shot injuries, traumas, osteomyelitis, cystic lesion and other maxilla pathologies are one of the most important issues having been studied in the maxillofacial surgery. Osseous tissue regeneration in postsurgical jaw gaps is a challenging process because of longlasting neogenesis (in cases when the healing period is required to be reduced), frequent cases of incomplete osseous tissue recovery and relatively high frequency of purulent complications [1-3].

(C) Kh. R. Pohranychna
According to the tissue engineering theory the availability of relevant cells (osteogenic progenitor cells and osteoblasts), signal molecules assuring osteoinduction (activating growth factors, morphogenic proteins), matrix made of the osteoplastic material specifying the osseous tissue space and form, in other words the development of launch environment necessary for the well-disposed proliferation of osseous tissues and capillaries in the defined space are required for the goal-oriented osseous tissue regeneration.

The autogenous osseous tissue with the osteogenic, osteoinductive and osteoconductive potential is the gold standard for the bone 
regeneration. As practice shows, despite the sufficient motivation the patients are reluctant to the reparative surgery being aware of the additional trauma inevitability. In the consideration of the foregoing, the maxillofacial surgeons have been in the recent years striving to optimize the reparative osteogenesis followed after the surgical intervention taking into account different factors among which the local application of various plastic stuff is predominant [4-7]. It is the authors' opinion that no universal osteoplastic material has been so far invented to be used in odontology for filling postsurgical bone gaps [8-10].

The search of appropriate implantation stuff widely used in the reparative maxillofacial surgery contributed to the application of the human placental cells being an easily available and economically advantageous biological material.

There is a great amount of collagen and yellow fibers in the placenta villus stroma at the end of pregnancy. Collagen is the main fibrillary protein containing amino acids actively engaged with cells promoting the reparative process. As far as osteoregeneration processes are similar with embryogenesis an idea of applying fetoplacental tissues for the plastic reconstruction of maxilla defects appeared [11].

Placenta is an active polyfunctional organ consisting of a great number of collagen fibres, synthesizing almost all hormones and over 40 fetal immunomodulating factors. It is a natural repository of vitamins, cytokines, peptides, $\alpha$-fetoproteins, antioxidants, adaptogenes and other biologically active agents stimulating reparative regeneration processes [12]. Placenta is a producer of many growth factors: insulinlike growth factor - a well-known mitogen for stromal fibroblasts; placental growth hormone - the main regulation hormone of insulin-like growth factors; vascular endothelial growth factor involved in angiogenesis [13]. Adjusting to the microenvironment conditions and answering the local organ- and tissue specific regulating signals the placenta biological implant serves as a "reparative construction material" performing morphogenesis function and recovering damaged structures [14]. A new compositional osteoplastic material Osteopor was made of (at the percent ratio) a double-phase porous bioceramics Kergap T-300 (55-60\%), lyophilized placenta fragments (30-35\%) and polymer blend consisting of polyvinyl alcohol and polyvinylpyrrolidone (5-10\%) serving as a binding component. The declaration patent of Ukraine was obtained for the invention No. $67927 \mathrm{~A}$. No data was found in the literary sources about the research of the combined use of hydroxyapatite (HA) and tricalcium phosphate (TCP) with placenta tissue for filing postsurgical maxilla defects.

The comparative experimental study of osseous tissue regeneration in the created foraminous mandibular defects being implanted with bioceramics Kergap T-300 and osteoplastic material Osteopor, as well as justifying the possibility of using the developed reparative material in the maxillofacial surgery clinics based on the analysis of histomorphological research results for are the paper objectives.

\section{METHODS}

78 nonlinear white male rats weighing 240-300 $\mathrm{g}$ with foraminous mandibular defects were used as models for studying impact on the reparative osteogenesis processes made by the osteoplastic material. The well-known standard method [15] was applied for conducting a surgery. Above abdominal anesthesia with $10 \%$ hexenalum solution at the rate of $0.6 \mathrm{mg}$ hexenalum per $100 \mathrm{~g}$ of the animal's mass. Having achieved the periosteum detachment and bone surface baring by means of a dental drill a perforated foraminous defect of $5 \mathrm{~mm}$ in diameter was made in the rat's mandibular angle by applying a conical dental cutter with a restrictor.

Periosteum was resected over the gap space in order to exclude the impact of paraosseous tissues on osteogenesis. The implant material was inserted into the created bone defects. The experiment consisted of three sets. The bone 
wound repair with a blood clot was observed in the first set of experiments (18 animals) being a test group. The double-phase bioceramics Kergap T-300 with the particle sizes of 0.25 $0.40 \mathrm{~mm}$ was inserted into the rats' mandibular defects in the second set (30 animals). The newly elaborated ompositional osteoplastic material Osteopor was used for the third set of experiments (30 animals).

The animals were sacrificed by ether anesthesia overdosing on the $7^{\text {th }}, 14^{\text {th }}, 21^{\text {st }}, 30^{\text {th }}$, $60^{\text {th }}$ and $90^{\text {th }}$ days. The jaw bone fragments with defects were removed, fixed in $10 \%$ neutral formalin solution, decalcified in $10 \%$ trilon B solution with the borate buffer $(\mathrm{pH}=7.2)$, dehydrated in the alcohols of increasing concentration and put in paraffin. Three histological sections of 10 mcIU thick were made by means of a microtome from each unit being stained in hematoxylin and eosin [16]. Reparative changes in the implantation sites were studied in real time with the help of histological drugs under the optical microscopy.

The received agents were investigated and taken micro photos by means of Leica Galen III microscope under 150 and 357 zooming. Histological studies were carried out to evaluate the graft structural organization and the osseous tissue enclosing the defect. Morphometric study was conducted with the application of spectacular inserts with measuring grids applied for cytohistostereometric research [17].

The graft components were the morphometry object calculated at the percentage ratio per the graft space unit in three cuts from each section. A big quadrate of the spectacular stereo logical grid containing 100 node points regarded as $100 \%$ of the graft square was the space unit. The spectacular grid points accidentally coinciding with the graft components were used to measure the volumetric percentage ratio of the osteoplastic material, connective and osseous tissues contained in the osseous graft allowing for the mathematical representation of the dynamic pattern in the course of the biological implant reconstruction.
The received numerical research findings were processed by means of the variation statistics method by means of the computer program STATISTICA for Windows 8.0 (Stat Soft, USA) used for medical and statistical computations.

\section{RESULTS AND THEIR DISCUSSION}

The special features of the osseous graft and new organotypic bone development in the created foraminous mandibular defects observed in rats from the experimental and control sets were compared by applying the histomorphological and morphometric methods. In $27.7 \%$ cases the rats' mandibular defects repair under the natural environment conditions of osseous tissue regeneration achieved with a blood clot was complicated by purulence, the surgical wound dehiscence with pyorrhea or perimandibular abscess. Having been revealed pyorrhea the animals were sacrificed. The remaining rats with no detected suppurative complications were observed the neutrophil leucocytic infiltration, intense macro- and microphagal detritus resorption up to 14-21 days after the surgery.

The development of cicatrical connective tissue, poor periosteal reaction manifested as the newly-made short and slightly winding bone trabeculas developed on the $21^{\text {st }}-30^{\text {th }}$ days of the experiment and partial defect filling of the defect with the slightly differentiated chondroid and osteoid graft are the main evidence of the reparative processes in this experiment set (Table1).

Along with the development of the osseous tissue the osteogenic structures of which are of disordered orientation in the graft peripheral sites no complete neogenesis of bone architectonics was evident in the defects even in three months of the bone regeneration during the experimental set. The graft structure was of mosaic type with the osteoid osseous tissue interchanging the immature fungoid polymorphic structure. A complicated low differentiated graft of the mixed chondroid-osteoid type was developed (Figure 1). 
Table 1. Morphometric characteristics of the rats' reparative regeneration of mandibular defects under the conditions of natural regeneration.

\begin{tabular}{|c|c|c|c|c|c|c|}
\hline \multirow[b]{2}{*}{$\begin{array}{c}\text { Day of } \\
\text { observation }\end{array}$} & \multicolumn{6}{|c|}{ Regenerate composition (\%): Me (min-max) [low-upper quartiles] } \\
\hline & $\begin{array}{l}\text { Blood clots, tis- } \\
\text { sue detrite }\end{array}$ & $\begin{array}{c}\text { Soft connec- } \\
\text { tive tissue }\end{array}$ & $\begin{array}{c}\text { Osteoid } \\
\text { connective } \\
\text { tissue }\end{array}$ & $\begin{array}{c}\text { Cartilage } \\
\text { tissue }\end{array}$ & $\begin{array}{l}\text { Rough-fiber } \\
\text { bone tissue }\end{array}$ & $\begin{array}{l}\text { Plate bone } \\
\text { tissue }\end{array}$ \\
\hline 7 & $\begin{array}{c}76(72-80) \\
{[75-78]}\end{array}$ & $\begin{array}{c}24(20-28) \\
{[22-25]}\end{array}$ & - & - & - & - \\
\hline 14 & $\begin{array}{c}53(48-58) \\
{[50-55]}\end{array}$ & $\begin{array}{c}39(36-42) \\
{[38-40]}\end{array}$ & $\begin{array}{c}5(4-6) \\
{[4-6]}\end{array}$ & $\begin{array}{c}4(3-5) \\
{[4-4]}\end{array}$ & - & - \\
\hline 21 & $\begin{array}{c}10(7-13) \\
{[8-12]}\end{array}$ & $\begin{array}{c}74(71-77) \\
{[73-75]}\end{array}$ & $\begin{array}{c}8(6-10) \\
{[7-9]}\end{array}$ & $\begin{array}{c}6(3-8) \\
{[5-8]}\end{array}$ & $\begin{array}{c}2(1-3) \\
{[2-2]}\end{array}$ & - \\
\hline 30 & - & $\begin{array}{c}69(67-71) \\
{[68-70]}\end{array}$ & $\begin{array}{c}12(9-15) \\
{[11-13]}\end{array}$ & $\begin{array}{c}8(7-9) \\
{[7-9]}\end{array}$ & $\begin{array}{c}11(9-14) \\
{[10-12]}\end{array}$ & - \\
\hline 60 & - & $\begin{array}{c}40(35-46) \\
{[37-43]}\end{array}$ & $\begin{array}{c}32(29-35) \\
{[30-34]}\end{array}$ & $\begin{array}{c}4(3-5) \\
{[3-5]}\end{array}$ & $\begin{array}{c}19(17-21) \\
{[18-20]}\end{array}$ & $\begin{array}{c}5(4-6) \\
{[4-6]}\end{array}$ \\
\hline 90 & - & $\begin{array}{c}25(23-27) \\
{[25-26]}\end{array}$ & $\begin{array}{c}39(36-42) \\
{[37-40]}\end{array}$ & $\begin{array}{c}2(1-3) \\
{[1-3]}\end{array}$ & $\begin{array}{c}25(22-27) \\
{[24-26]} \\
\end{array}$ & $\begin{array}{c}9(7-11) \\
{[8-10]}\end{array}$ \\
\hline
\end{tabular}

The slow osteogenesis of defects achieved with a blood clot can be explained by the lack of the sufficient amount of cells, their poor density during the first and next regeneration stages and osteogenesis conditions unfavourable for osteogenesis, thus, confirming the necessity of replacing postsurgical defects with plastic materials in order to optimize osteoreparative processes.

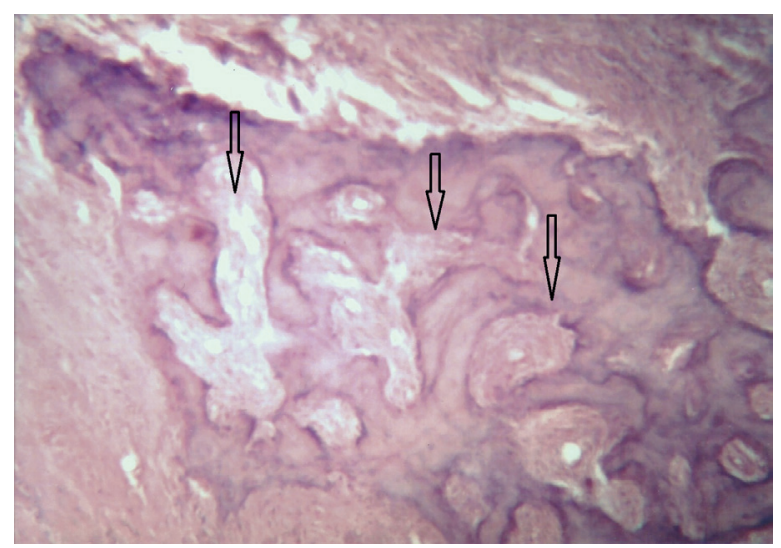

Figure 1. The bone defect filled with the neogenic osseous tissue of different maturity level and connective tissue. Haematoxylin and eosin staining. Zoom -150 . The $90^{\text {th }}$ day of the experiment. Test group
Having analysed the results obtained in the $2^{\text {nd }}$ and $3^{\text {rd }}$ sets of the experiment some consistent patterns were revealed in the course of implantation material replacement. On the 14 day of observation in animals of the 3rd series capillary net in the regenerate have been developed. The optimization of the cellular fibroblast proliferation and differentiation, the osteoblastic tissue formation in the graft and its further reformation starting from the $14^{\text {th }}$ day of the experiment were the characteristic features of the osseous tissue neogenesis (Table 2).

Presumable dynamics $(\mathrm{P}<0.05)$ in terms of all morphometric aspects of osseous regeneration as compared to the previous sampling and between the both experimental animals groups was determined in the course of the study.

The comparison of the experimental findings gave us the grounds for stating about more active reparative regeneration in the created rats' mandibular defects filled with the compositional biological stuff Osteopor versus the defects filled with Kergap. As a result of the active resorption the osteoplastic material was comprising less than a half of the graft space in only three weeks 
Table 2. Morphometric aspects of the rats' mandibular defects regeneration after their being replaced with Kergap T (K) and Osteopor (O) osteoplastic materials.

\begin{tabular}{|c|c|c|c|c|c|c|c|c|c|c|}
\hline \multirow{3}{*}{ Day } & \multicolumn{10}{|c|}{ Regenerate composition (\%): Me (min-max) [low-upper quartiles] } \\
\hline & \multicolumn{2}{|c|}{$\begin{array}{c}\text { Bonegraft mate- } \\
\text { rial }\end{array}$} & \multicolumn{2}{|c|}{$\begin{array}{l}\text { Soft connective } \\
\text { tissue }\end{array}$} & \multicolumn{2}{|c|}{$\begin{array}{l}\text { Osteoid connec- } \\
\text { tive tissue }\end{array}$} & \multicolumn{2}{|c|}{$\begin{array}{c}\text { Rough-fiber bone } \\
\text { tissue }\end{array}$} & \multicolumn{2}{|c|}{ Plate bone tissue } \\
\hline & K & $\mathrm{O}$ & K & $\mathrm{O}$ & K & $\mathbf{O}$ & $\mathbf{K}$ & $\mathbf{O}$ & $\mathbf{K}$ & $\mathbf{O}$ \\
\hline \multirow{3}{*}{7} & 85 & 73 & 12 & 19 & 2 & 7 & & 1 & & \\
\hline & $(82-88)$ & $(70-76$ & $(10-13)$ & $(17-22)$ & $(1-5)$ & $(5-9)$ & - & $(0-2)$ & - & - \\
\hline & [83-87] & {$[71-75]$} & [11-13] & [18-20] & [2-5] & [6-8] & & [1-1] & & \\
\hline \multirow{3}{*}{14} & 77 & 60 & 16 & 22 & 6 & 12 & 1 & 6 & & \\
\hline & $(74-80)$ & $(57-63)$ & $(15-17)$ & $(19-25)$ & $(4-8)$ & $(9-15)$ & $(0-2)$ & $(4-8)$ & - & - \\
\hline & [75-79] & [58-62] & [15-17] & [20-24] & {$[5-7]$} & [10-14] & {$[1-1]$} & [5-7] & & \\
\hline \multirow{3}{*}{21} & 66 & 44 & 18 & 26 & 11 & 17 & 5 & 9 & & 4 \\
\hline & $(63-69)$ & $(41-47)$ & $(15-21)$ & $(18-28)$ & $(8-14)$ & $(14-20)$ & $(3-7)$ & $(7-14)$ & - & $(3-7)$ \\
\hline & [64-68] & [42-46] & [16-20] & [19-28] & [8-14] & [15-19] & [3-7] & [8-13] & & [4-7] \\
\hline \multirow{3}{*}{30} & 55 & 32 & 17 & 15 & 14 & 22 & 9 & 17 & 5 & 14 \\
\hline & $(52-58)$ & $(29-35)$ & $(14-20)$ & $(12-19)$ & $(12-16)$ & $(19-25)$ & $(6-12)$ & $(14-20)$ & $(3-7)$ & $(12-16)$ \\
\hline & [53-57] & [30-34] & [16-19] & [13-17] & [13-15] & [20-24] & [7-11] & [15-19] & [3-7] & [13-15] \\
\hline \multirow{3}{*}{60} & 43 & 18 & 16 & 9 & 17 & 21 & 14 & 22 & 10 & 30 \\
\hline & $(40-47)$ & $(15-21)$ & $(14-18)$ & $(7-14)$ & $(14-20)$ & $(14-25)$ & $(12-16)$ & $(19-25)$ & $(1-13)$ & $(24-38)$ \\
\hline & [41-44] & [16-20] & [15-17] & [8-13] & [16-19] & [18-23] & [13-15] & [20-24] & [7-13] & [26-34] \\
\hline \multirow{3}{*}{90} & 38 & 5 & 13 & 6 & 17 & 18 & 17 & 21 & 15 & 53 \\
\hline & $(35-40)$ & $(4-6)$ & $(11-15)$ & $(5-7)$ & $(14-20)$ & $(15-21)$ & $(14-20)$ & $(14-25)$ & $(13-18)$ & $(43-60)$ \\
\hline & [37-39] & {$[5-5]$} & [12-14] & [5-7] & [16-19] & [16-20] & [16-18] & [18-23] & [14-16] & [46-56] \\
\hline
\end{tabular}

following the surgery with the application of Osteopor. For 60 days - loose and instant masses of composite material were imbued with osteoid tissue full of capillaries.

The closure of the bone trabecular grid having been developed in the soft connective tissue resulted in the early formation of rough fibrous osseous tissue and spongy structure. Later it underwent the oppositional growth with osteoblasts playing the main role, forming new osseous tissue layers and making a sheet structure. The newly formed bone mineralization was accomplished due to the physical and chemical reprecipitation of calcium and phosphate having been released from the implant material and due to the osteoblasts.

The neogenic rough-fiber and plate bone tissue elements were comprising 52 (43-63)[46$58] \%$ and $74(57-85)[64-79] \%$ of the bone graft in 60 and 90 days after the surgical intervention correspondingly. In cases of Kergap-T application it was equal to $24(13-29)[20-28] \%$ and 32 (27-38)[30-34]\% correspondingly. In cases of "Osteopor" application the plate bone element of the graft was comprising 53 (43-60)[46-56]\% by the end of the experiment while the use of Kergap-T resulted only in 15 (13-18)[14-16\%].

By the end of the experiment the latter comprised $1 / 3$ of the graft space which was equal to 38 (35-40)[37-39]\% being hidden in the osseous tissue. Consequently, according to the morphometric research, the osseous tissue development, maturing and secondary reconstruction of osseous structures, as well as biodegradation of composite material substances were faster and the maturity of the osseous tissue was observed by the end of the experiment in the group of animals with the Osteopor used for filling the created bone defects (Figures 2a, 2b). 
Figure 2a) The enlargement of osseous graft with the hidden Kergap-T granules

Figure 2b) Neogenic osseous tissue with the evidence of compaction

This resulted from the intense reparative osteogenesis developed under the conditions of constant engagement with the composition material implanted into the bone defect. High porosity of the material simplified the fast implant revascularisation, as well as the migration and proliferation of osteoplastic peripheral blood cells and the surrounding loose connective tissue. Being a biologically active material Osteopor promoted angiogenesis, migration, the attachment of stromal cells, their differentiation into osteoblasts and further reparative osteogenesis.

At that, osteogenesis was developing in two directions: from the periphery towards the center due to the proliferation of spongeous mandibular osteoblasts and from the central cavity area towards the periphery being the result of the neogenic bone trabeculas newly formed in the loose connective tissue and presented as "spot osteogenesis" areas. The latter was not observed in cases when Kergap-T was applied.

\section{SUMMARY}

The repair of created foraminous mandibular defects achieved with a blood clot in the

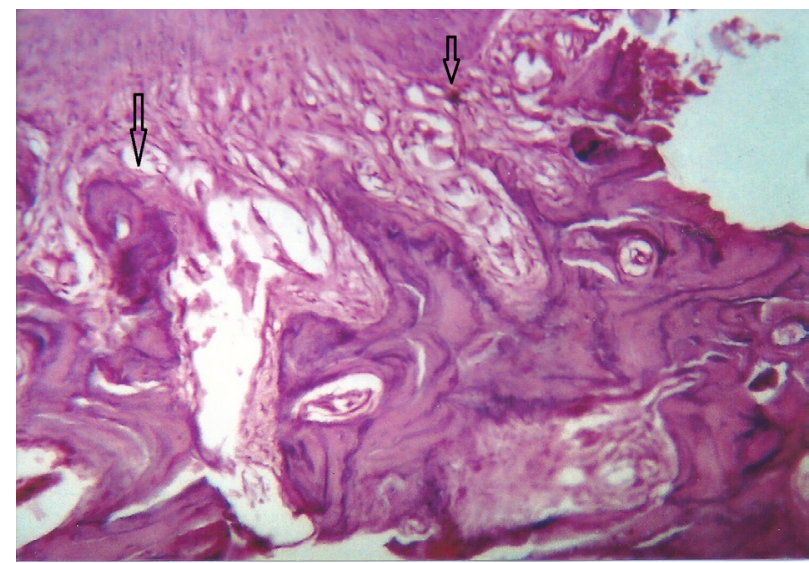

a course of the experiment was complicated with the defect stuff purulence (in $27.7 \%$ cases). In other cases regeneration caused the development of heterogeneous graft made of chondroid-fibroblastic and osteoid tissues of different organization levels. The comparative experimental morphological and histomorphometric studies of the bone regeneration involving the replacement of created jaw defects with osteoplastic material Kergap-T alone and in the combination with the lyophilized biological placenta implant Osteopor proved that the latter speeded up the beginning of active regenerative processes promoting the early defect filling with the neogenic organotypic osseous tissue.

The availability of lyophilized placenta fragment (LPF) in the osteoplastic material promoted HA (hydroxyapatite) and TCP (tricalcium phosphate) bioresorption, fast development and mineralization of the osseous graft. Osteopor proved to have osteogenesis promoting properties due to the following aspects of the implant elements: 1) lyophilized placenta fragments (LPF) being the source of biologically active agents, in particular, polypeptide osteogenesis factors, serve as the inductors for the osteoblastic cell population and for the secretion of bone matrix proteins; LPF assure microenvironment favourable for osteogenesis,

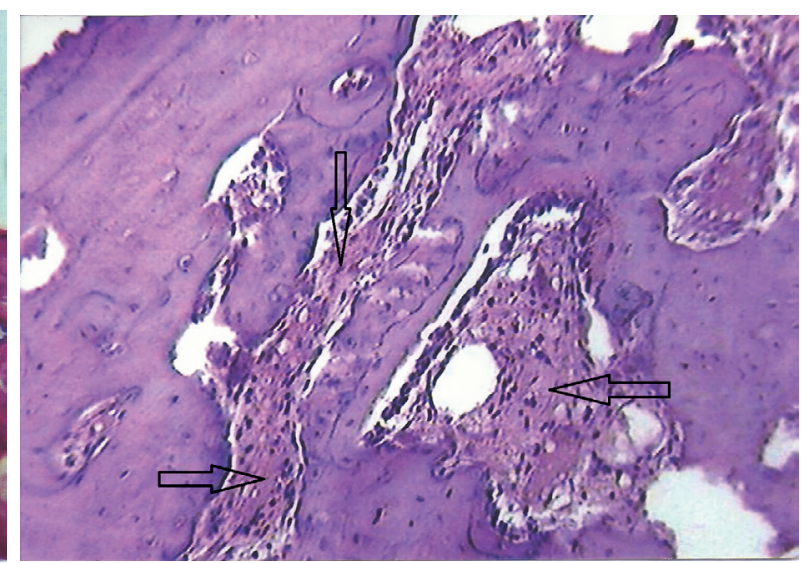

6

Figure 2. the $90^{\text {th }}$ day of the experiment. The bone defect filled with Kergap (a) and Osteopor (b). Haematoxylin and eosin staining. Zoom -150 
intercellular fluid diffusion and fast graft vascularization; 2) activating proliferation of fibroblasts and their biosynthetical function the placenta collagen promotes collagen development; 3) depositing and restraining the osteogenetic cell material Kergap-T serves as a frame gradually reabsorbing and being replaced with the normal osseous tissue. Kergap-T assures the neogenic bone mineralization due to the physical and chemical reprecipitation of calcium and phosphate having been released from the implant material.

Consequently, according to the experimental study findings the offered composition plastic material Osteopor was proved to have osteoinductive and osteoconductive effects assuring the development of a compact osseous tissue. Thus, it is recommended for the clinical use as an osseointegrated implant effective for the stimulation of reparative osteogenesis in the wound jaw defect area.

\section{Х.Р.Погранична}

\section{РЕПАРАТИВНІ ПРОЦЕСИ ЩЕЛЕПНИХ КІСТОК ПРИ ЗАСТОСУВАННІ РІЗНИХ ОСТЕОПЛАСТИЧНИХ МАТЕРІАЛІВ}

Метою нашої роботи було вивчення у порівняльному аспекті в експерименті процесів регенерації кісткових тканин у штучних дірчастих дефектах нижньощелепних кісток при імплантації в них біокераміки Кергап Т-300 та остеопластичного матеріалу Остеопор, та на основі аналізу результатів гістоморфологічних досліджень обгрунтувати можливість застосування розробленого нами пластичного матеріалу в клініці щелепно-лицевої хірургії. Вплив пластичного матеріалу на репаративні процеси остеогенезу вивчали на моделі дірчастих дефектів нижньої щелепи у 78 лабораторних білих щурів. Гістологічні дослідження проводили для оцінки структурної організації регенерату і стану кісткової тканини, що оточувала дефект. Об'єктом морфометрії були складові компоненти регенерату, які підраховувалися у відсотковому відношенні на одиницю площі регенерату в трьох зрізах кожного блоку. Загоєння штучно утворених дірчастих кісткових дефектів нижньої щелепи в експерименті під кров'яним згустком у $27,7 \%$ ускладнювалося нагноєнням вмісту дефекту. В інших випадках регенерація призводила до утворення неоднорідного регенерату з хондрофібробластичної та остеоїдної тканин на різних стадіях організації. Порівняльні експериментальні морфологічні та гістоморфометричні дослідження регенерації кістки при заміщенні штучно утворених кісткових дефектів щелеп остеопластичним матеріалом Кергап Т самостійно і в композиції з ліофілізованим біоімплантатом 3 плаценти - Остеопором показали, що останній прискорює початок активних процесів регенерації, сприяє ранньому заповненню дефекту новоутвореною органотиповою кістковою тканиною, яка через 60 діб після операції становила 52(43-63)[46-58]\%, а через 90 - 74(57-85)[64-79]\% кісткового регенерату, тоді як при застосуванні матеріалу Кергап Т -24(13-29) [20-28]\% і 32(27-38)[30-34]\% відповідно. Морфометричні дослідження засвідчили, що при застосуванні Остеопору частка пластинчастої кістки в регенераті до кінця експерименту становила 53 (43-60) [46-56]\%, в той час, як при застосуванні Кергапу Т - 15(13-18) [14-16]\%.

Ключові слова: репаративний остеогенез; плацентарна тканина; кістково-пластичні матеріали.

\section{Х.Р.Пограничная}

\section{РЕПАРАТИВНЫЕ ПРОЦЕССЫ ЧЕЛЮСТ- НЫХ КОСТЕЙ ПРИ ПРИМЕНЕНИИ РАЗЛИЧНЫХ ПЛАСТМАСС}

Целью нашей работы было изучение в сравнительном аспекте в эксперименте процессов регенерации костных тканей в искусственных дырчатых дефектах нижнечелюстных костей при имплантации в них биокерамики Кергап Т-300 и остеопластического материала Остеопор, и на основе анализа результатов гистоморфологичних исследований обосновать возможность применения разработанного нами пластического материала в клинике челюстно-лицевой хирургии. Влияние пластического материала на репаративные процессы остеогенеза изучали на модели дырчатых дефектов нижней челюсти у 78 лабораторных белых крыс. Гистологические исследования проводили с целью оценки структурной организации регенерата и состояния костной ткани, окружавшей дефект. Объектом морфометрии были компоненты регенерата, которые подсчитывались в процентном отношении на единицу площади регенерата в трех срезах каждого блока. Заживление искусственно образованных дырчатых костных дефектов нижней челюсти в эксперименте под кровяным сгустком в 27,7\% осложнялось нагноением содержания дефекта. В других случаях регенерация приводила к образованию неоднородного регенерата с хондрофибробластичнои и остеоидного тканей на разных стадиях организации. Сравнительные экспериментальные морфологические и гистоморфометрични исследования регенерации кости при замещении искусственно созданных костных дефектов челюстей остеопластическим материалом Кергап Т самостоятельно и в комбинации с лиофилизированным биоимплантатом из плаценты - Остеопором показали, что последний ускоряет начало активных процессов регенерации, способствует раннему заполнению дефекта новообразованной органотипических костной тканью, 
которая через 60 сут после операции составляла 52 (43$63)[46-58] \%$, а через 90 - 74 (57-85) [64-79]\% костного регенерата, тогда как при применении материала Кергап Т - соответственно 24 (13-29) [20-28]\% и 32 (27-38) [30$34] \%$. Морфометрические исследования свидетельствуют, что при применении Остеопора доля пластинчатой кости в регенерате к концу эксперимента составляла 53 (43-60) [46-56]\%, в то время, как при применении Кергап Т - 15 $(13-18)[14-16] \%$.

Ключевые слова: репаративный остеогенез; плацентная ткань; костно-пластиченкие материалы.

\section{REFERENCES}

1. Rubio ED, Mombrú CM. Spontaneous bone healing after cysts enucleation without bone grafting materials: a randomized clinical study. Craniomaxillofac Trauma Reconstr. 2015;8(1):14-22.

Tee B, Desai G, Sonnichsen B. Reconstructing jaw defects with MSCs and PLGA-encapsulated growth factors J Transl Res. 2016; 8(6): 2693-2704.

2. Zhao JH, Tsai CH, Chang YC. Management of radicular cysts using platelet-rich fibrin and bioactive glass: a report of two cases. J Form Med Assoc. 2014;113(7):470-6.

3. Pavlenko OV, Dmitriyeva YE. Morphological bases of choice of bone graft materials in parodontology. Morphology. 2011; 5(1):5-12. [Ukrainian].

4. Wagdargi SS, Rai KK, Arunkumar KV, Katkol B. Evaluation of Spontaneous Bone Regeneration after Enucleation of Large Cysts of the Jaws using Radiographic Computed Software. J Contemp Dent Pract. 2016;17(6):489-95

5. Vovk V, Vovk Y. Clinically-biometric and x-ray densitometry assessment tissue defects alveolar processes of the jaws during their bone tissue regeneration. Dentalnews. 2012; 4:36-44.
6. Kattimani VS, Chakravarthi PS, Prasad LK. Biograft Block: A Ray of Hope in the Reconstruction of Maxillofacial Defects. J Craniofac Surg. 2016;27(1):247-52.

7. Hertsen Y. Experimental aspects combinative plastics of cavity defects using different compelex materials on the basis of hydroxyapatite. Chronicl Traumatol and Orthoped. 2014; 1(2):85-87.

8. Mysula I, Skochylo O. Bone-plastic materials for the replacing of jaw defects: from the past to the present Hosp Surg. 2013;3:97-101.

9. Makeyev V, Siryi O, Cherpak M, Slipyi V. Comperative experimental evaluation of reparative osteogenesis of jaw bone defects filled in by different osteoplastic biografts. Dentalnews 2010; 1:42-45.[Ukrainian].

10. Murphy BF, Brandley MC, Murphy CR, Thompson MB. Morphology and development of the placentae. J Anat. 2012; 220(5): 454-71.

11. Hryshchenko V, Shcherbyna N, Tanko O, Potapova L, Kuzmina I. Fetal, cell and tissue therapy: results and perspectives of application. Obstet Gynecol. 2001; 2: 6-8. [Russian].

12. Hryshchenko V, Holtsev A. Transplantation of the embrioplacental complex. Probl Cryobiol. 2002; 1:54-64. [Russian].

13. Hryshchenko V, Holtsev A. Modification of lymphohemopoetic complex of the organism in conditions of fetoplacental products complex application. Transplantology 2001;3: 5. [Russian].

14. Luzin V. Method of bone defects modeling in laboratory animals. Ukr Med Almanc. 2005; 8(2):162.[Ukrainian].

15. Sarkisov D, Perov Y. Microscopical technique Moscow: Medicine 2006; 542p. [Russian].

16. Avtandilov H. Medical morphometry. Moscow: Medicine 2010;383p. [Russian]. 